\title{
Control system for ecological modernization of enterprises (on the example of the Republic of Armenia) ${ }^{1}$
}

\author{
Andranik S. Akopov \\ Professor, Department of Business Analytics \\ National Research University Higher School of Economics \\ Address: 20, Myasnitskaya Street, Moscow, 101000, Russian Federation \\ E-mail:aakopov@hse.ru
}

\section{Armen L. Beklaryan}

Lecturer, Department of Business Analytics

National Research University Higher School of Economics

Address: 20, Myasnitskaya Street, Moscow, 101000, Russian Federation

E-mail:abeklaryan@hse.ru

\section{Armen K. Saghatelyan}

Director, Center for Ecological-Noosphere Studies

National Academy of Sciences of the Republic of Armenia

Address: 68, Abovian Street, Yerevan, 0025, Republic of Armenia

E-mail: ecocentr@sci.am

\section{Lilit V. Sahakyan}

Deputy Director, Center for Ecological-Noosphere Studies

National Academy of Sciences of the Republic of Armenia

Address: 68, Abovian Street, Yerevan, 0025, Republic of Armenia

E-mail: lilit.sahakyan@cens.am

\begin{abstract}
The article examines a system for controlling the ecological modernization dynamics of enterprises developed with the help of simulation modelling methods and implemented using the example of the Republic of Armenia (RA). The system has been developed for strategic decision-making directed at modernization of enterprises of RA, their transformation from an initial non-ecological state towards the state of ecologically pure manufacturing.

The main feature of the software developed is an original agent-based model describing the dynamics of the ecological-economics system. The system has been implemented using the AnyLogic platform. This model is integrated with a multidimensional data warehouse, genetic optimizing algorithm (modified for the bi-objective optimization problem of an ecological-economics system), a subsystem of simulation results visualization (Graphs, Google Maps) and other software modules designed with use of the Java technologies.

The target functionalities of the bi-objective optimization problem of the ecological-economics system are minimized integrated (accumulated) volume of total emissions into the atmosphere and maximized integrated (averaged) index of industrial production of the agent's population. The problem was formulated and solved for the first time. Moreover, values of objectives are calculated by means of simulation, as the result of activity of all agent-enterprises in a population and taking into account their internal interaction. The 270 enterprises of RA which are the main stationary sources of emissions of harmful substances were selected for the research. In addition, there is a generalized agent-consumer and the agent-government completing ecological regulation through the mechanisms of penalties, subsidies and rates of emissions fees. The simulation core is the developed algorithm of behavior for each agent-enterprise providing the mechanism of agent transition from an initial non-ecological state towards other possible states. At the same time, control of the evolutionary dynamics of agents is implemented with the help of the suggested genetic algorithm. As a result, the system we developed makes it possible to search Pareto-optimal decisions for a bi-objective optimization problem of the agent-based ecological-economics system.
\end{abstract}

${ }^{1}$ This work was supported by the Russian Foundation for Basic Research (grant no. 15-51-05011) 
Key words: agent-based modeling, simulation modeling, ecological-economics system, genetic algorithms, multicriteria optimization.

Citation: Akopov A.S., Beklaryan A.L., Saghatelyan A.K., Sahakyan L.V. (2016) Control system for ecological modernization of enterprises (on the example of the Republic of Armenia). Business Informatics, no. 2 (36), pp. 71-78. DOI: 10.17323/1998-0663.2016.2.71.78.

\section{Introduction}

$\mathrm{D}$ eciding about a modernization (transformation) of enterprises in the direction of ecologically pure manufacturing (low-waste) is a difficult task that requires you to develop an agent-based simulation model in order to consider the agent-enterprises behavior individually [1-2].

The complex solution for such problem requires the creation of a hybrid intelligent system seeking the best trade-offs among possible decisions on the ecological modernization of enterprises.

It should be noted that such intelligent systems can be built on simulation models aggregated with evolutionary optimization algorithms through the target functions, in particular, with genetic algorithms [3-4].

The simulation modelling [5] is a very effective tool for investigating the dynamics of complex systems and it can be applied in support of a mechanism of the adaptive, in particular, strategical control of such systems [6-7, 13].

Designing simulation models can be based on using together the system dynamics methods [8] and agentbased modelling [9] and as well as on the intelligent integration of developed models with evolutionary algorithms type of genetic algorithms intended for a multicriteria optimization [10].

In modern times, a novel direction is taking shape, which is related to the creation of agent-based simulations for ecological-economics systems [12]. The use of such models to form and visualize Pareto optimal subsets [14] has special interest.

Thus, this work is devoted to an original informationanalytical system designed with the use of simulation modelling methods and it is intended for control of the dynamics of the ecological modernization of enterprises as implemented in the Republic of Armenia.

The main users of the system are departments of the government ecological regulation, the Ministry of Natural Resources and Environment, the Ministry of Emergency Situations and other regulators.

Initial datasets have been provided for simulation modeling by the Center of Ecological-Noosphere Stud- ies of the National Academy of Sciences of the Republic of Armenia. The system developed has been published on the Internet and is available on the website http:// smartersim.com/ecmodel.

It should be noted that at this stage we have investigated only problems of minimization of emissions in the atmosphere without taking note of other components (for example, water pollution, soil pollution, etc.).

\section{Simulation \\ of the ecological-economics system}

The formal description of the model and bi-objective optimization problem of the ecological-economics system will be considered below. Thus, the system has some target functions. They are the Integrated Volume of Total Emissions (expected and accumulated for the simulation period that equals a period of strategic planning) and the Integrated Index of Industrial Production. The main objective consists in searching for the best trade-offs allowing you to maximize the first objective and minimize the second objective through rational control of the dynamics of transformation of agent-enterprises from their initial non-ecological state toward a target state of ecologically pure manufacturing.

There are 270 agent-enterprises characterized by significant emissions levels, the generalized consumer and agent-government that carry out ecological regulation in the model.

\section{Let's denote:}

$\triangleleft j \in\{1,2, \ldots, J(t)\}-$ the index of the agents-enterprises having stationary sources of emissions;

$\checkmark s_{j} \in\left\{1,2, \ldots, S_{j}(t)\right\}-$ the index of stationary sources of emissions of $j$-th agent-enterprise (if the parameter $\omega_{s j}=0$, then the $s_{j}$-th source of emissions is closed, if $\omega_{s j}=1$, then the $s_{j}$-th of emissions is saved);

$\downarrow t \in\left\{t_{0}, t_{0}+1, \ldots, t_{0}+T\right\}-$ the simulation time by years ( $T$ the strategical planning horizon, that equals ten years: $2016-2025)$;

$\delta_{j} \in\{1,0\}-$ the matrix of transitions between possible states of for an $j$-th agent-enterprise - the control 
parameter, that sets up with the help of suggested genetic algorithm (if $\delta_{j}=1$, the transition from the current state to new stats for an $j$-th agent-enterprise is allowed, if $\delta_{j}=0$ the transition is blocked);

$s t_{j}(t) \in\{1,2,3,4\}-$ possible states of an $j$-th agententerprise (if $s t_{j}(t)=1$, it is non-ecological manufacturing, if $s t_{j}(t)=2$, it is partial modernization, if $s t_{j}(t)=3$, it is ecologically pure manufacturing, if $s t_{j}(t)=4$, it is a closed enterprise);

$\lambda_{j}(t)-$ the share of subsidies in the investment expenditure of an $j$-th agent-enterprise that will be paid in the case of transition to the state of a partial modernization. It is set up by an agent-government $\left(0 \leq \lambda_{j}(t) \leq 1\right)$;

$\eta_{j}(t)$ - the share of penalties in the profit of an $j$-th agent-enterprise that will be paid in case the emission limit is exceeded. It is set up by an agent-government $\left(0 \leq \eta_{j}(t) \leq 1\right)$;

$-E_{j}\left(s t_{j}(t)\right)$ - the total emissions of an $j$-th agent-enterprise that depends on its current state $s t_{j}(t) \in\{1,2$, $3,4\}$. If $s t_{j}(t)=1$, the volume of the total emissions is a maximum. If $s t_{j}(t)=4$, there is no emissions;

$\checkmark E_{j}$ - the limit of total emissions for $j$-th agent-enterprises, which is set up for each agent-enterprise individually (taking into account the geographic location, remoteness from settlements and other parameters);

$\checkmark V_{j}\left(s t_{j}(t)\right)$ - the volume of output of an $j$-th agententerprise that depends on its state $s t_{j}(t) \in\{1,2,3,4\}$. While the state of the agent is changing, its volume of the output that depends on the production capacity and the production efficiency is changing, too. Production capacity is going down and production efficiency is being increased in the process of the ecological modernization of an agent-enterprise.

$\checkmark V_{j}(t-1)-$ the volume of output of an $j$-th agententerprise for a previous year;

$\downarrow \sum_{j=1}^{J(t)} \frac{V_{j}(t)}{V_{j}(t-1)}-$ the index of the physical volume of industrial production for a population of agent-enterprises;

$\downarrow \sum_{j=1}^{J(t)} E_{j}(t)-$ the total emissions for the population of agent-enterprises;

$\checkmark P_{j}^{\prime}\left(s t_{j}(t) \in 1\right)$ - the profit of an $j$-th agent-enterprise calculated for the first state of a non-ecological manufacturing;

$P_{j}^{\prime \prime}\left(s t_{j}(t) \in 2\right) P_{j}^{\prime \prime \prime}\left(s t_{j}(t) \in 3\right)-$ the profit of an $j$-th agent-enterprise calculated for the second and the third states of a partial and full state respectively; $z_{j}(t)-$ the relative ecological ranking of $j$-th agententerprise:

$$
z_{j}(t)=\frac{E_{j}(t)}{\sum_{j=1}^{J(t)} E_{j}(t)} ;
$$

$\downarrow p(t)$ - a small random number (generated by the randomizer);

$\checkmark\left\{\tau_{1}, \tau_{2}, \tau_{3}\right\}$ - the known time delays that relate to transitions to new states (in the range of $1-3$ years), which are caused by the inertial process of the ecological modernization.

The suggested algorithm of agent-enterprise behavior is based on analysis of potential advantages of transitions to new states through the ecological modernization if appropriate financial possibilities are available. At the same time, the agent-government can incentivize such transitions, in particular, through the subsidies and penalties, and the growth of emissions fee rates. As a result of this, the ecologically regulated profit will be more for a new state for an agent-enterprise. Hence, the new state is preferable for the agent. On the other hand, the agent-government can restrict such transitions with the help of technological and financial limitations.

If $\delta_{j}(t)=1$, the speed of the ecological modernization of an $j$-th agent-enterprise will be maximum, however this also causes reduced production capacities and even the full closure of the enterprise if the ecological laws and limitations are exceeded for some years.

Such an effect for the population of agent-enterprises can cause a reduction of the integrated index of industrial production.

Thus, possible states of an $j$-th agent-enterprise are:

$$
s t_{j}(t)=\left\{\begin{array}{l}
1, \text { if } t \in t_{0} \text { or } s t_{j}(t) \notin\{2,3,4\}, \\
2, \text { if } \delta_{j}\left(t-\tau_{1}\right)=1 \text { and } \\
\left(P_{j}^{\prime \prime}\left(s t_{j}(t) \in 2\right) \geq P_{j}^{\prime}\left(s t_{j}(t) \in 1\right) \text { or } z_{j}(t) \geq p(t)\right), \\
3, \text { if } \delta_{j}\left(t-\tau_{2}\right)=1 \text { and } \\
\left(P_{j}^{\prime \prime \prime}\left(s t_{j}(t) \in 3\right) \geq P_{j}^{\prime \prime}\left(s t_{j}(t) \in 2\right) \text { or } z_{j}(t) \geq p(t)\right), \\
4, \text { if } \delta_{j}\left(t-\tau_{3}\right)=1 \text { and }\left(E_{j}(t)>E(t)\right. \text { and } \\
\left.\omega_{s_{j}}=0 \text { for all } s_{j} \in\left\{1,2, \ldots, S_{j}(t)\right\}\right)
\end{array}\right.
$$

The formula (1) means that each agent-enterprise considers its ecological state regarding the whole population of agent-enterprises. 
If growth of total emissions for the agent-enterprise regarding other agents is observed, the probability of its transition to a new state is increasing too.

At the same time, the main factor having an impact on such transition is the estimation of the potential profit in comparison with the current profit which is completed by the agent-enterprise, as well as the external control $\delta_{j}(t) \in\{1,0\}$.

We can now formulate the bi-objective optimization problem of the ecological-economics system.

The problem. The need to maximize the Integrated Index of Industrial Production and to minimize the Integrated Volume of Total Emissions for the whole population of agent-enterprises:

$$
\left\{\begin{array}{c}
\max _{\delta_{j}(t)}\left[\sum_{t=t_{0}}^{t_{0}+T} \sum_{j=1}^{J(t)} \frac{V_{j}(t)}{V_{j}(t-1)}\right], \\
\min _{\delta_{j}(t)}\left[\sum_{t=t_{0}}^{t_{0}+T} \sum_{j=1}^{J(t)} E_{j}(t)\right],
\end{array}\right.
$$

under restrictions:

$$
\begin{aligned}
& \delta_{j}(t) \in\{1 ; 0\}, \\
& s t_{j}(t) \in\{1,2,3,4\} \\
& 0 \leq \eta_{j}(t) \leq 1,0 \leq \lambda_{j}(t) \leq 1 \\
& j \in\{1,2, \ldots, J(t)\} \\
& t \in\left\{t_{0}, t_{0}+1, \ldots, t_{0}+T\right\} .
\end{aligned}
$$

and other restrictions having a clear economic sense (for example, the limit of investment capital).

In work [1] we see the description of the main model characteristics of the ecological-economics system of the Republic of Armenia in more detail.

The problem (3) was solved with the help of the genetic optimization algorithm that was developed, as modified for application in multi-agent large-scale systems [10]

Such an algorithm is related to the type of the SPEA2 (Strength Pareto Evolutionary Algorithm). Its base implementation is described in the work [11]. In contrast to the previously developed algorithms of SPEA и SPEA2, the genetic algorithm suggested in this work was adapted for the problem of binary control of transitions between possible states of agents. Hence, it takes into account the specifics of multi-agent simulation systems under optimization.

As a result, the minimization of agents target functions (on the level of fitness-functions) is carried out without coding (and decoding) of appropriate chromosomes in the discrete decisions space, limited by possible states of an agent.
The aggregation of the genetic algorithm with the simulation model on the agent level allows us to improve significantly the time efficiency of the procedure for seeking non-dominated decisions (Pareto optimal decisions), because it reduces the length of chromosomes and the population size significantly.

Thus, the use of the suggested genetic algorithm for the control of agent transitions is necessitated firstly by the large-scale optimization problem (the evolutionary dynamics of 270 agents having many of their own parameters is optimized for a horizon of planning equal to 10 years). Secondly, it is necessitated by the specifics of the needed evolution of non-dominated decisions without using the difficult operations of coding and decoding chromosomes, which usually precede operations of crossing over and mutation.

\section{The software system developed}

The system developed is intended for those seeking the best trade-offs in the context of the bi-objective optimization problem (3) considered and it allows us, in particular:

\ To simulate "What-IF" scenarios for the analysis of effects of different parameters of the government ecological regulation system on the main characteristics of the ecological-economics system (for example, on the dynamics of total volume of emissions; on the number of diagnosed diseases caused by emissions in the atmosphere; on the number of non-ecological, partial ecological, closed enterprises; on equilibrium fee rates for emissions by kinds of emissions, etc.).

To form the subset Pareto optimal decisions to seek the best trade-offs. That means to carry out optimization experiments for the bi-objective problem of the ecological-economics system considered, target functions of which are the integrated (accumulated for the strategical planning period) volume of total emissions and the integrated index of industrial production (estimated for the whole population of agent-enterprises).

The following main technologies were applied to develop the information system:

$\downarrow$ AnyLogic - a simulation system which allows you to implement hybrid models based on both system dynamics methods and agent-based modelling methods;

MS SQL Server - a data warehouse which is used as a data base for statistical datasets (by agents), as well as for saving (rewriting) and transferring the simulation results; 
JSF (Java Server Faces) - the software platform for web-applications built on Java program language; it is used for the creation of the user interface which is integrated with the simulations on the AnyLogic (they are independent Java-modules), with the data base of the system (through the $J D B C$ ), with the developed genetic algorithm $(E J B)$ and geographical maps (Google Maps) to visualize the evolutionary dynamics of agents.

The aggregated architecture of the software system is represented in Figure 1.

It should be noted that the system functionality consists of such blocks as "What-If" experiments; optimization experiments, the visualization of scenarios characteristics of the ecological-economics systems; the visualization of the Pareto-front; the visualization and analysis of local decisions which can be picked up on the front; the visualization of the evolutionary dynamics of agent-enterprises on the geographical map.

The respective information is represented on the website of the system in more detail http://smartersim.com/ ecmodel.

\section{Results of simulation modeling}

The main result of the simulation modeling is the Pareto-front that was formed with the help of the suggested genetic algorithm for the bi-objective optimiza- tion problem of the considered ecological-economics system in the Republic of Armenia (Figure 2).

As shown in the Figure 2, the best decisions from the government point of view are decisions on ecological modernization (the matrix $\delta_{j}(t) \in\left\{\begin{array}{ll}1,0 & 0\end{array}\right.$, $j \in\{1,2, \ldots, J(t)\})$ characterized by an Integrated Volume of Total Emissions which does not exceed 1.5 million tons and an Integrated Index of Industrial Production which is more than $100 \%$, meaning positive manufacturing growth.

It should be noted that investigations of different scenarios for the development of the ecological-economics system of the Republic of Armenia have been completed. They include the scenario without modernization $\left(\delta_{j}=0\right.$ for all $\left.j \in\{1,2, \ldots, J(t)\}\right)$, the scenario of "fast" modernization $\left(\delta_{j}=1\right.$ for all $\left.j \in\{1,2, \ldots, J(t)\}\right)$, and the scenario of the "Pareto optimal modernization" $\delta_{j}(t) \in\{1,0\}$ calculated with the help of the suggested genetic algorithm.

As the result of the simulation, we obtained the best scenario for the ecological-economics system: the scenario of the "Pareto optimal modernization", whereby the Integrated Volume of Total Emissions has been reduced by $25 \%$ compared with the initial scenario (without modernization) while assuring positive growth of the industrial production (when the Integrated Index of Industrial Production is more than $100 \%$ ).

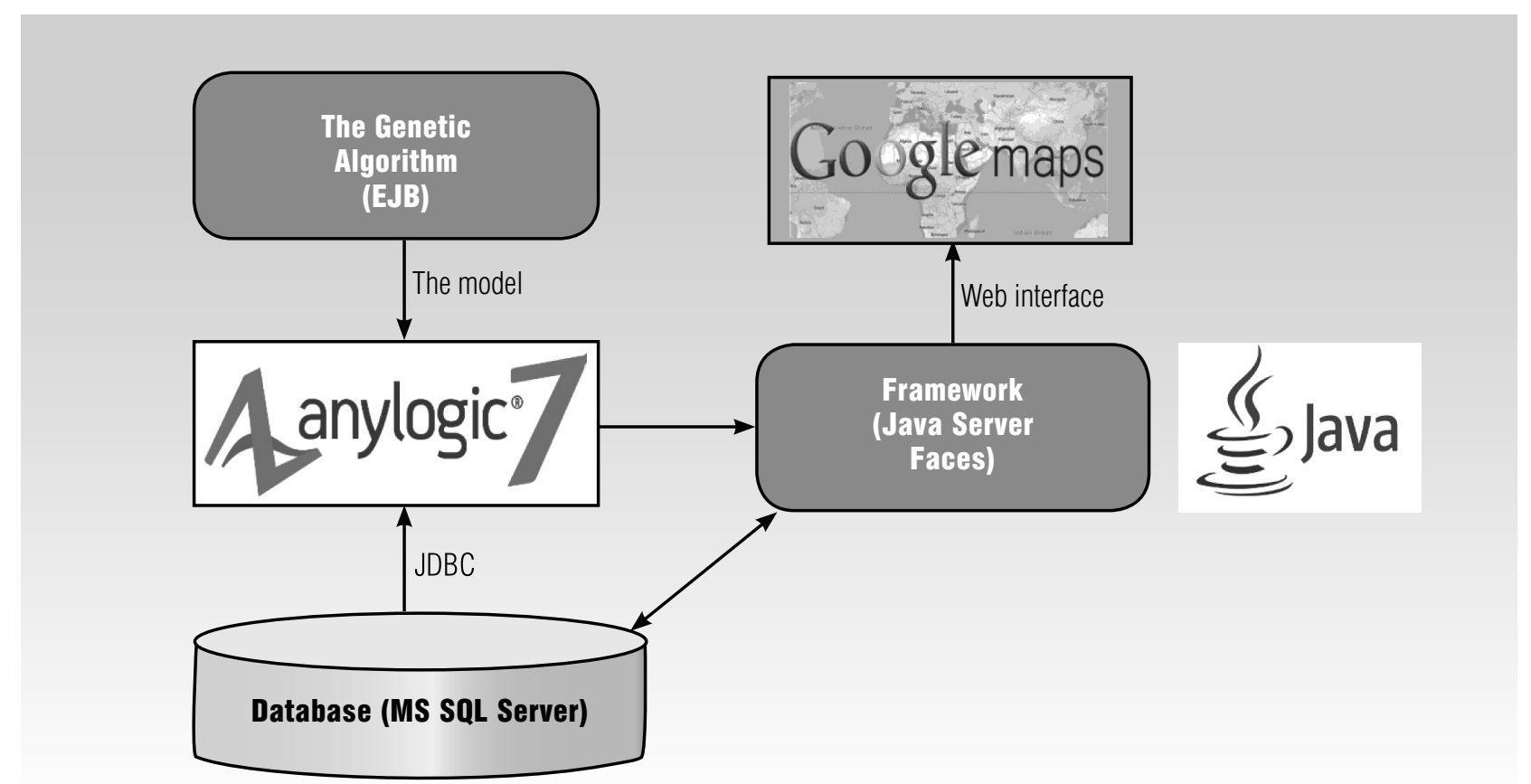

Fig. 1. The aggregated architecture of the software system 
Integrated Index of Industrial Production (\%)

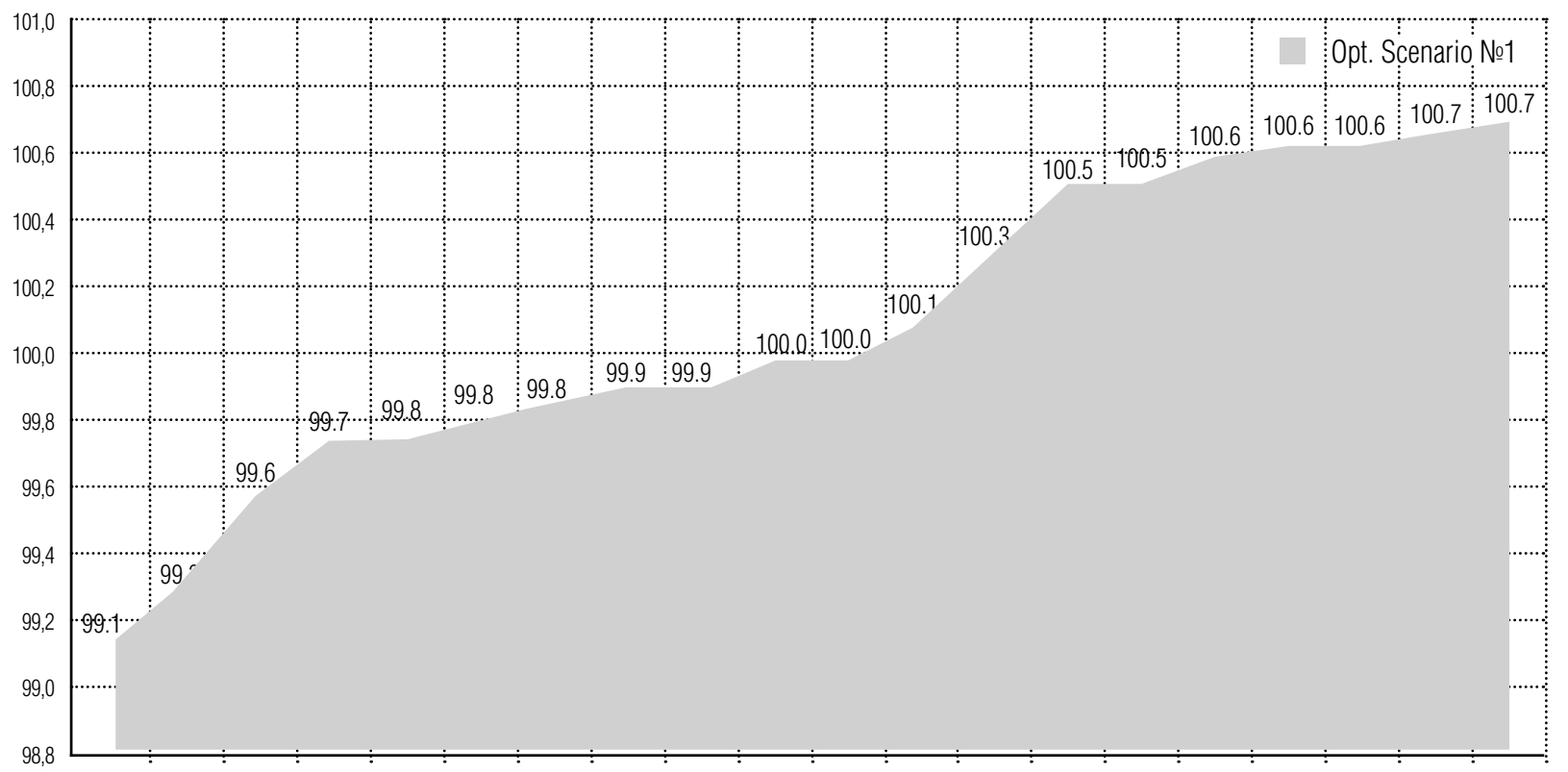

$\begin{array}{llllllllllllllllllllll}1379,52 & 1398,85 & 1400,54 & 1421,76 & 1429,5 & 1429,78 & 1445,53 & 1458,67 & 1482,54 & 1496,17 & 1501,3 & 1501,21 & 1666,77 & 1679,95 & 1685,7 & 1686,86 & 1692,92 & 1701,86 & 1711,67 & 1720,52\end{array}$ Integrated Volume of Total Emissions (thousand tons)

Fig. 2. The Pareto-front for the bi-objective optimization problem of the ecological-economics system

\section{Conclusion}

Thus, we developed a new software system which is intended for researching the impact of important parameters of government regulation on the main characteristics of the ecological-economics system, and it is being implemented in the Republic of Armenia. The software system can be adapted for other countries and regional ecological-economics systems if the datasets required are available. The feature of the system we created is the developed agent-based simulation implemented with the AnyLogic platform and integrated with the suggested genetic algorithm, data warehouse, and a geographical map like Google Map to visualize the evolutionary dynamics of agent-enterprises. The results obtained confirm the existence of optimal scenarios for ecological modernization that significantly reduce the level of total emissions into the atmosphere while safeguarding positive dynamics of industrial production.

\section{References}

1. Akopov A.S., Beklaryan A.L., Beklaryan L.A., Saghatelyan A.K. (2016) Modelirovanie regional'noy ekologo-ekonomicheskoy sistemy s mekhanizmom gosudarstvennogo regulirovaniya na primere Respubliki Armeniya [Modeling of a regional ecological-economics system with statutory regulations mechanism on the example of Republic of Armenia]. Economics of Contemporary Russia, no. 1 (72), pp. 109-119 (in Russian).

2. Akopov A.S., Beklaryan L.A., Beklaryan A.L., Saghatelyan A.K. (2014) Ukrupnennaya model' ekologo-ekonomicheskoy sistemy na primere Respubliki Armeniya [The integrated model of eco-economic system on the example of the Republic of Armenia]. Computer Research and Modeling, vol. 6, no. 4, pp. 621-631 (in Russian).

3. Akopov A.S., Beklaryan G.L. (2009) Intellektual'nye gibridnye sistemy upravleniya vertikal'no-integrirovannymi organizatsionnymi strukturami [Intelligent hybrid management systems for vertically integrated organizational structures]. Preprint. Series WP/2009/267. Moscow, CEMI RAS (in Russian).

4. Akopov A.S. (2010) K voprosu proektirovaniya intellektual'nykh sistem upravleniya slozhnymi organizatsionnymi strukturami. Ch1. Matematicheskoe obespechenie sistemy upravleniya investitsionnoy deyatel'nost'yu vertikal'no-integrirovannoy neftyanoy kompanii [On the issue of developing of intelligent control systems of complex organizational structures. Part 1. Mathematical support for control system of the vertically integrated oil company investment activities]. Control Sciences, no. 6, pp. 12-18 (in Russian).

5. Akopov A.S. (2014) Imitatsionnoe modelirovanie [Simulation modeling]. Moscow, Urait (in Russian).

6. Akopov A.S. (2004) Ispol'zovanie sredstv dinamicheskogo imitatsionnogo modelirovaniya dlya podgotovki upravlencheskikh resheniy v TEK [Using dynamic simulation modeling for management decisions preparation in fuel-energy complex]. Control Systems and Information Technologies, no. 2 (14), pp. $72-77$ (in Russian). 
7. Akopov A.S., Beklaryan L.A. (2011) Model of adaptive control of complex organizational structures. International Journal of Pure and Applied Mathematics, vol. 71, no. 1, pp. 105-127.

8. Akopov A.S. (2012) Sistemno-dinamicheskoe modelirovanie strategii bankovskoy gruppy [System dynamics modeling of banking group strategy]. Business Informatics, no. 2 (20), pp. 10-19 (in Russian).

9. Akopov A.S., Beklaryan L.A. (2015) An agent model of crowd behavior in emergencies. Automation and Remote Control, vol. 76, no 10, pp. $1817-1827$.

10. Akopov A.S., Hevencev M.A. (2013) A multi-agent genetic algorithm for multi-objective optimization. Proceedings of IEEE International Conference on Systems, Man and Cybernetics, Manchester, 13-16 October 2013. P. 1391-1395.

11. Bleuler S., Brack M., Thiele L., Zitzler E. (2001) Multiobjective genetic programming: Reducing bloat by using SPEA2. Proceedings of Congress on Evolutionary Computation (CEC 2001), Piscataway, NJ, 2001. P. 536-543.

12. Heckbert S., Baynes T., Reeson A. (2010) Agent-based modeling in ecological economics. Annals of the New York Academy of Sciences, no. 1185 , pp. 39-53.

13. Isaev D.V. (2011) Razvitie sistem informatsionnoy podderzhki korporativnogo upravleniya i strategicheskogo menedzhmenta [Development of information support systems for corporate governance and strategic management]. Business Informatics, no. 2 (16), pp 56-62 (in Russian).

14. Lotov A.V., Bushenkov V.A., Kamenev G.K. (2004) Interactive decision maps. Approximation and visualization of the Pareto frontier. Boston: Kluwer Academic Publishers.

\section{Система управления динамикой экологической модернизации предприятий (на примере Республики Армения) ${ }^{1}$}

\section{A.C. Aкопов}

доктор технических наук, профессор кафедры бизнес-аналитики

Национальный исследовательский университет «Высшая школа экономики»

Адрес: 101000, г. Москва, ул. Мясницкая, д. 20

E-mail:aakopov@hse.ru

\section{А.Л. Бекларян}

преподаватель кафедры бизнес-аналитики

Национальный исследовательский университет «Высшая школа экономики»

Адрес: 101000, г. Москва, ул. Мясницкая, д. 20

E-mail: abeklaryan@hse.ru

\section{А.K. Сагателян}

доктор геолого-минералогических наук, директор Центра эколого-ноосферных исследований

Национальная академия наук Республики Армения

Адрес: 0025, г. Ереван, ул. Абовяна, д. 68

E-mail: ecocentr@sci.am

\section{Л.В. Саакян}

кандидат географических наук, заместитель директора Центра эколого-ноосферных исследований

Национальная академия наук Республики Армения

Адрес: 0025, г. Ереван, ул. Абовяна, д. 68

E-mail: lilit.sahakyan@cens.am

\section{Аннотация}

Статья посвящена системе управления динамикой экологической модернизации предприятий, разработанной с использованием методов имитационного моделирования и реализованной на примере Республики Армения (РА). Система предназначена для обеспечения поддержки принятия стратегических решений по модернизации предприятий РА с целью их трансформации из исходного неэкологического состояния в направлении экологически чистого (малоотходного) производства.

Особенностью разработанного программного комплекса является, прежде всего, оригинальная агентная модель, описывающая динамику эколого-экономической системы, реализованная с использованием 
платформы AnyLogic. Данная модель интегрирована с многомерным информационным хранилищем, генетическим оптимизационным алгоритмом (модифицированным для задачи бикритериальной оптимизации эколого-экономической системы), подсистемой визуализации результатов моделирования (графики, карты Google Maps) и другими программными модулями, спроектированными с использованием технологий Јava.

Впервые сформулирована и решена бикритериальная оптимизационная задача эколого-экономической системы, функционалами которой являются минимизируемый интегрированный (накопленный) объем совокупных выбросов вредных веществ в атмосферу и максимизируемый интегрированный (усредненный) индекс физического объема выпуска (популяции предприятий). При этом значения целевых функционалов вычисляются с помощью разработанной имитационной модели как результат деятельности всей популяции агентов-предприятий, с учетом их внутреннего взаимодействия. Для исследования были отобраны 270 предприятий РА, являющихся основными стационарными источниками выбросов вредных веществ. В модели имеется обобщенный агент-потребитель, а также агент-государство, реализующий экологическое регулирование через механизмы штрафов, субсидий и ставок платежей за выбросы. Ядром модели является разработанный алгоритм поведения каждого агента-предприятия, обеспечивающий механизм перехода агента из исходного неэкологического состояния к другим возможным состояниям. При этом управление эволюционной динамикой агентов осуществляется с использованием предложенного генетического алгоритма. В результате разработанная система позволяет осуществлять поиск оптимальных по Парето решений для бикритериальной оптимизационной задачи рассматриваемой эколого-экономической системы агентного типа.

Ключевые слова: агентное моделирование, имитационное моделирование, эколого-экономическая система генетические алгоритмы, многокритериальная оптимизация.

Цитирование: Akopov A.S., Beklaryan A.L., Saghatelyan A.K., Sahakyan L.V. Control system for ecological modernization of enterprises (on the example of the Republic of Armenia) // Business Informatics. 2016. No. 2 (36). P. 71-78.

DOI: 10.17323/1998-0663.2016.2.71.78.

\section{Литература}

1. Акопов А.С., Бекларян А.Л., Бекларян Л.А., Сагателян А.К. Моделирование региональной эколого-экономической системы с механизмом государственного регулирования на примере Республики Армения // Экономическая наука современной России. 2016. № 1 (72). С. 109-119.

2. Акопов А.С., Бекларян Л.А., Бекларян А.Л., Сагателян А.К. Укрупненная модель эколого-экономической системы на примере Республики Армения // Компьютерные исследования и моделирование. 2014. Т. 6, № 4. С. 621-631.

3. Акопов А.С., Бекларян Г.Л. Интеллектуальные гибридные системы управления вертикально-интегрированными организационными структурами / Препринт. Сер. WР/2009/267. М.: ЦЭМИ РАН, 2009.

4. Акопов А.С. К вопросу проектирования интеллектуальных систем управления сложными организационными структурами. Ч1 Математическое обеспечение системы управления инвестиционной деятельностью вертикально-интегрированной нефтяной компании // Проблемы управления. 2010. № 6. С. 12-18.

5. Акопов А.С. Имитационное моделирование. М.: Юрайт, 2014. 389 с.

6. Акопов А. С. Использование средств динамического имитационного моделирования для подготовки управленческих решений в ТЭК // Системы управления и информационные технологии. 2004. № 2 (14). С. 72-77.

7. Akopov A.S., Beklaryan L.A. Model of adaptive control of complex organizational structures // International Journal of Pure and Applied Mathematics. 2011. Vol. 71. No. 1. P. 105-127.

8. Акопов А.С. Системно-динамическое моделирование стратегии банковской группы // Бизнес-информатика. 2012. № 2 (20). C. $10-19$.

9. Akopov A.S., Beklaryan L.A. An agent model of crowd behavior in emergencies // Automation and Remote Control. 2015. Vol. 76. No 10. P. $1817-1827$.

10. Akopov A.S., Hevencev M.A. A multi-agent genetic algorithm for multi-objective optimization // Proceedings of IEEE International Conference on Systems, Man and Cybernetics, Manchester, 13-16 October 2013. P. 1391-1395.

11. Bleuler S., Brack M., Thiele L., Zitzler E. Multiobjective genetic programming: Reducing bloat by using SPEA2 // Proceedings of Congress on Evolutionary Computation (CEC 2001), Piscataway, NJ, 2001. P. 536-543.

12. Heckbert S., Baynes T., Reeson A. Agent-based modeling in ecological economics // Annals of the New York Academy of Sciences. 2010. No. 1185. P. 39-53.

13. Исаев Д.В. Развитие систем информационной поддержки корпоративного управления и стратегического менеджмента // Бизнес-информатика. 2011. № 2 (16). С. 56-62.

14. Lotov A.V., Bushenkov V.A., Kamenev G.K. Interactive decision maps. Approximation and visualization of the Pareto frontier. Boston: Kluwer Academic Publishers, 2004. 